\title{
Colorado Family Physicians and Medical Marijuana: Has Recreational Marijuana Changed Physician Attitudes and Behaviors?
}

\author{
Elin C. Kondrad, MD and Alex J. Reed, PsyD, MPH
}

Introduction: Medical marijuana is permitted in 36 states; 15 states allow recreational marijuana use. Previous surveys showed that family physicians were concerned about the physical and mental health effects of medical marijuana use, but the impact of recreational marijuana legalization and liberalization of marijuana laws on physician attitudes is unknown.

Methods: A survey was distributed to 1582 members of the Colorado Academy of Family Physicians' listserv, with items on individual and practice characteristics and experience with and attitudes toward medical marijuana. The results of this survey were compared with that of a nearly identical survey conducted with the same group in 2011.

Results: The proportion of family physician respondents in Colorado recommending medical marijuana to patients was the same in 2020 as in 2011 at 31\%; 53\% of physicians said that legislation allowing recreational marijuana did not change their approach to medical marijuana with patients. Family physicians were more likely to be in favor of legalization of recreational marijuana in 2020 than in 2011.

Conclusions: Marijuana decriminalization and a robust marijuana economy in Colorado have not led to more family physicians recommending marijuana to patients, but there is now greater support for the legalization of recreational marijuana among family physicians. ( $\mathrm{J}$ Am Board Fam Med 2022;35:102-114.)

Keywords: Cannabis, Colorado, Family Medicine, Family Physicians, Health Behavior, Medical Marijuana, Primary Health Care, Surveys and Questionnaires

\section{Introduction}

The United States has seen a dramatic change in the landscape around marijuana legislation over the past 25 years, starting with a successful California ballot measure permitting medical marijuana use in 1996. The past decade has seen particularly rapid change, with 20 states passing medical marijuana

This article was externally peer reviewed.

Submitted 19 March 2021; revised 22 August 2021; accepted 26 August 2021.

From St. Joseph Family Medicine Residency, Denver, CO (ECK); Department of Family Medicine, University of Colorado School of Medicine, Denver, CO (AJR).

Funding: This research was supported by in-kind support from St. Joseph Family Medicine Residency and statistical support from the University of Colorado Department of Family Medicine. There were no external funding sources.

Conflict of interest: The authors have no relationships, conditions, or circumstances that present a potential conflict of interest to disclose.

Corresponding author: Elin C. Kondrad, MD, St. Joseph Family Medicine Residency, 1375 E 19th Ave, Denver, CO 80218 (E-mail: elin.kondrad@sclhealth.org). legislation and 15 states passing laws allowing recreational marijuana use. Medical marijuana use is now permitted in 36 states and the District of Columbia, with 15 of these states additionally permitting recreational marijuana use. ${ }^{1}$

While people use marijuana for a variety of conditions, the evidence for the benefits of medical marijuana is limited in quality and is largely based on studies of US Food and Drug Administration (FDA)-approved synthetic cannabinoids rather than the preparations used by most medical marijuana patients. ${ }^{2-6}$ How have primary care physicians navigated the evolution of marijuana from an illicit substance to a potential medical therapy they are responsible for recommending to patients? How has that approach changed now that marijuana is now also a legal recreational drug in many states? We originally sought to answer this first question in 2011, after legislation permitting medical marijuana in Colorado but before subsequent legislation 
that allowed for recreational marijuana use, by surveying family physicians about their attitudes and practices around medical marijuana. At that time, most respondents were skeptical of marijuana's medical benefits and concerned about adverse effects; fewer than $20 \%$ believed physicians should recommend medical marijuana to patients, and $30 \%$ of physicians surveyed thought that marijuana should be legalized for recreational use. ${ }^{7}$

More recently, similar but smaller surveys of physicians in Minnesota and New York have shown higher rates of acceptance of marijuana as medical therapy, with more than $50 \%$ of providers believing that it was helpful in treating certain medical conditions. ${ }^{8,9}$ A study of medical students in Colorado showed similar concerns as those voiced in our 2011 survey about risks of use but higher levels of approval of legalization of recreational marijuana. ${ }^{10}$ In small national samples of emergency medicine physicians, neurologists, and oncologists, most respondents felt that marijuana was helpful in treating certain medical conditions, with varying rates of approval for legalization of recreational marijuana. ${ }^{1-13}$ It is unclear whether the differences between the results of these surveys are due to differing attitudes because of location, age, or other demographics, or if they represent broader changes in physician attitudes over time in response to more permissive marijuana laws. There is evidence that as marijuana use increases among teens, perception of risk decreases among their age group, ${ }^{14}$ but there have been no studies documenting whether physician perception of risk similarly decreases with increasing availability and use of marijuana.

This article presents the results of a 2020 survey of the same community of physicians that completed our 2011 survey and was designed to address the question of whether physician support for and comfort with marijuana as a medical therapy has changed in the setting of this increased availability of marijuana. Colorado is an ideal setting for such a study because our 2011 Colorado study remains 1 of the largest studies on physician attitudes toward medical marijuana, making it a good baseline for comparison, and because in the interim since the 2011 study, Colorado has developed a mature economy around marijuana. Colorado leads the country in state revenue from marijuana, which surpassed $\$ 1$ billion in 2019, ${ }^{15}$ and in per-person spending on marijuana, which was $\$ 290$ in $2019 .{ }^{16}$ Colorado currently has 39,806 people licensed to work in the marijuana industry ${ }^{17}$ and a well-developed marijuana tourism industry. ${ }^{18}$ Our hypothesis was that more liberal laws governing marijuana use have led to more favorable physician attitudes about medical marijuana in the years since the initial survey.

\section{Methods}

We distributed an online survey to the 1582 members of the Colorado Academy of Family Physicians (CAFP) e-mail listserv in January 2020. Each subject received an e-mail reminder to complete the survey 2 weeks after the initial distribution and a second reminder approximately 4 weeks after initial distribution.

The 3-part survey began with demographic information, including age, gender, years in practice, and whether the subject had an unrestricted medical license. The second part assessed respondents' experience with medical marijuana, including whether they had ever recommended medical marijuana to a patient, how many times, and for which medical conditions; which factors most influenced their decision to recommend or not recommend medical marijuana; and from which sources they obtained most of their information about medical marijuana. In the third part, respondents were asked to rate, on a 5-point Likert scale, the extent to which they agreed or disagreed with 17 statements about marijuana policy in Colorado and nationally (eg, legalization of marijuana for recreational use, reclassifying marijuana so that it is no longer a Schedule I drug, and distribution of medical marijuana through a dispensary model), the risks and benefits of marijuana use, and educational opportunities about marijuana at various levels of medical training. The survey instrument is presented in Appendix 2.

The survey was identical to the 2011 survey distributed by the same author, with the exception of updating subsequently approved medical conditions for which physicians in Colorado can recommend medical marijuana (post-traumatic stress disorder [PTSD] in 2017 and autism spectrum disorders in 2019) and the addition of 1 question that asked whether legalization of recreational marijuana had changed the respondent's approach to medical marijuana. Both surveys were distributed by the CAFP to the listserv of its active family physicians. The study protocol and survey instrument were approved by the SCL Health Institutional Review 
Board. No external funding was received for this study.

Numeric responses were tabulated and summarized using counts and percentages. To facilitate bivariate comparisons, we collapsed responses to the 17 Likert scale items into "agree" (agree and strongly agree) and "disagree" (disagree and strongly disagree), excluding "neither agree nor disagree," as was done with the 2011 survey's data analysis. We then compared the responses of those who had recommended marijuana for a patient and those who had not using the $\chi^{2}$ test for independence. The $\chi^{2}$ test was also used to compare responses from this survey to those of the 2011 survey, specifically to determine whether there were significant differences in the proportion of subjects who agreed versus disagreed with each of the Likert scale items. Statistical analysis was performed using $\mathrm{JMP}^{\circledR}$ Pro software, version 15.0.0.

\section{Results}

A total of 235 responses were obtained for a response rate of $15 \%$. Table 1 summarizes respondents' age, gender, and whether or not they had unrestricted medical licenses, compared with the overall membership of the CAFP in this 2020 study compared with the same demographic characteristics for the 2011 study respondents.

Thirty-one percent of surveyed physicians reported ever recommending medical marijuana to a patient. Of these, $41 \%$ had recommended medical marijuana to between 1 and 5 patients in the previous 12 months, and $21 \%$ had not recommended medical marijuana to any patients in the previous 12 months. The overall proportion of physicians who had ever recommended medical marijuana to a patient remained the same between 2011 and 2020 at $31 \%$ in both survey samples. Of note, $44 \%$ of physicians said that their practice had a policy around formally recommending medical marijuana to a patient; of physicians with such a practice policy, $71 \%$ (31\% of the total sample) said that this prohibited them from recommending marijuana to patients.

Figure 1 summarizes the medical indications for which survey respondents reported recommending marijuana for both the 2011 survey sample and the current 2020 survey. A larger percentage of physicians had recommended medical marijuana for all conditions in 2020 compared with 2011 with the exception of muscle spasm and nausea.

Figure 2 depicts the sources where physicians reported getting most of their information about medical marijuana in the 2011 survey sample and

Table 1. Colorado Academy of Family Physicians (CAFP) Member Demographics versus Survey Respondent Demographics in 2011 and 2020

\begin{tabular}{|c|c|c|c|c|}
\hline & Number (\%) & Number (\%) & Number (\%) & Number (\%) \\
\hline Age & 2020 Survey Respondents & 2020 CAFP Members & 2011 Survey Respondents & 2011 CAFP Members \\
\hline 20 to 29 & $25(11)$ & $95(5)$ & $41(8)$ & $243(12)$ \\
\hline 30 to 39 & $77(33)$ & $541(28)$ & $87(17)$ & $448(23)$ \\
\hline 40 to 49 & $34(15)$ & $425(22)$ & $152(30)$ & $499(25)$ \\
\hline 50 to 59 & $49(21)$ & $440(23)$ & $161(32)$ & $464(23)$ \\
\hline 60 to 69 & $49(21)$ & $284(15)$ & $65(13)$ & $206(10)$ \\
\hline $70+$ & $1(<1)$ & $9(<1)$ & $5(1)$ & $98(5)$ \\
\hline Unknown & 0 & $114(6)$ & 0 & NA \\
\hline \multicolumn{5}{|l|}{ Gender } \\
\hline Male & $107(46)$ & $866(45)$ & $284(56)$ & $1078(54)$ \\
\hline Female & $127(54)$ & $964(51)$ & $224(44)$ & $913(46)$ \\
\hline Other/no response & 0 & $78(4)$ & 0 & NA \\
\hline \multicolumn{5}{|l|}{ Unrestricted license } \\
\hline Yes & $211(90)$ & & $460(90)$ & \\
\hline No & $21(9)$ & & $46(9)$ & \\
\hline
\end{tabular}

CAFP, Colorado Academy of Family Physicians.

Note that the number of active CAFP members is larger than the number who subscribe to the CAFP listserv to whom the survey was sent. 
Figure 1. Indications for which family physicians recommended medical marijuana. "Surveyed FPs" indicates the percentage of survey respondents who had recommended medical marijuana for each indication in the 2011 survey sample and the 2020 survey sample (only the $31 \%$ of physicians who had recommended marijuana to a patient in each of these samples were asked to answer this question). Medical conditions on the left are the approved conditions for which physicians can recommend medical marijuana in Colorado. Note that post-traumatic stress disorder (PTSD) and autism spectrum disorder became indications for medical marijuana recommendation in 2017 and 2019, respectively, so those indications were not assessed in the 2011 sample. Abbreviation: FP, family physician.

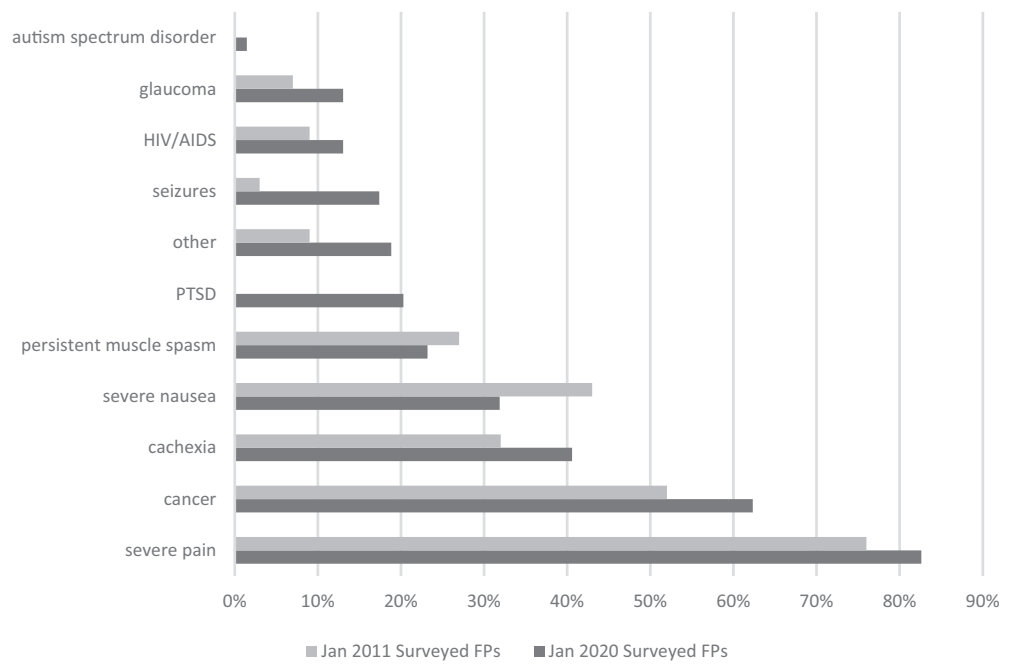

the 2020 survey. The 2 most common sources of information both in 2011 and in 2020 were medical literature and experiences with patients. There was an increase in the percentage of physicians who reported receiving most of their information from lecture, continuing medical education (CME), and other physicians, while the percentage of physicians who cited news media as a source decreased from $51 \%$ to $23 \%$.
The majority of responding physicians (53\%) said that legalization of recreational marijuana in Colorado had not changed their approach to medical marijuana. Similar percentages of respondents said that it had made them more likely to recommend marijuana to patients for medical purposes $(22 \%)$ as said that it had made them less likely to do so $(19 \%)$.

Figure 2. Family physicians' sources of information on medical marijuana. The figure shows the percentage of physicians who indicated that they received most of their information about medical marijuana from each of the sources on the 2011 survey versus the 2020 survey. Respondents were allowed to select more than 1 response, so percentages add up to $>100 \%$. Abbreviation: CME, continuing medical education.

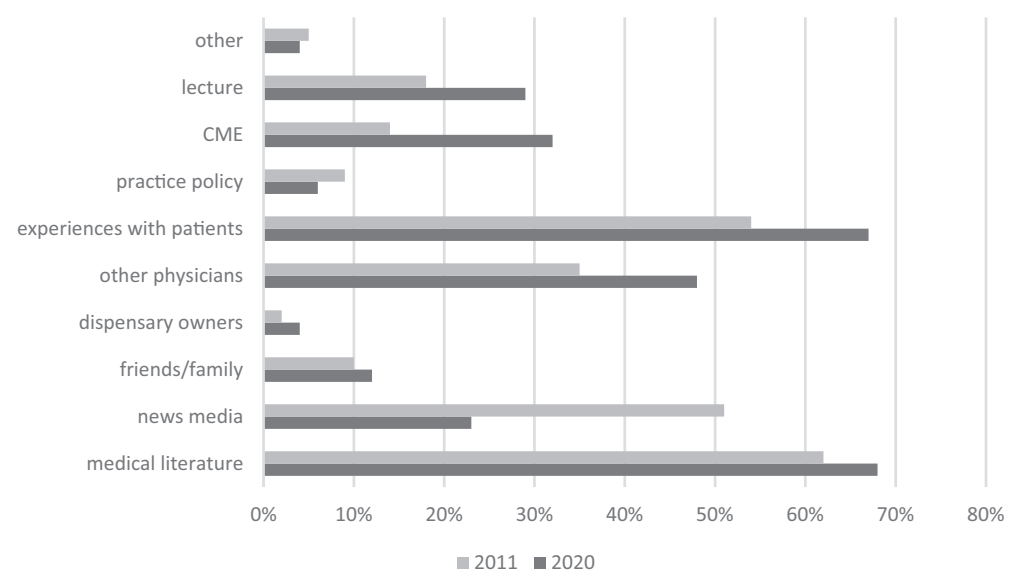


The tabulated Likert scale responses to the 17 opinion statements are presented in Appendix 1, with data from the 2011 survey included for comparison. In the 2020 sample, $49 \%$ percent of physicians chose "neither agree nor disagree" about whether physicians should recommend marijuana as a medical therapy, with $39 \%$ disapproving of this practice and $12 \%$ agreeing that physicians should recommend medical marijuana. Most surveyed physicians agreed that there were significant physical and mental health risks to marijuana use. Fewer than $20 \%$ of respondents believed that there were significant physical or mental health benefits to marijuana use.

There were differences in opinion between those physicians who had recommended medical marijuana to at least 1 patient when compared with those who had never recommended marijuana to a patient, as shown in Table 2. Those who had ever recommended medical marijuana were more likely to be convinced of its benefits and less concerned about its risks. There were no significant differences between the groups when asked whether medical marijuana should be included in the state database for monitoring controlled substances, whether doctors should have ongoing relationships with their patients, whether training on medical marijuana should be incorporated into medical school and family medicine residency curricula, and whether CME on medical marijuana should be available to primary care physicians.

Finally, the responses for each of these opinion statements were compared between the 2011 sample and the 2020 sample, as shown in Table 3. There were significant differences in the responses for 6 of these items, with respondents in 2020 more likely than those in 2011 to agree that the FDA should reclassify marijuana so that it is no longer a Schedule I drug, that marijuana should be legalized for recreational use, that medical marijuana should be distributed through the current dispensary model, and that training on medical marijuana should be incorporated into medical school curricula. Respondents were less likely to agree in 2020 than in 2011 that medical marijuana should be included in the Colorado Prescription Drug Monitoring Program and that doctors should avoid financial relationships with marijuana dispensaries. Most of these changes between 2011 and 2020 represented a change in the proportion of respondents who agreed with a statement rather than opposing opinions (eg, while respondents in 2020 were significantly more likely to agree than respondents in 2011 that medical marijuana should be distributed using the current dispensary model, most respondents in both years still

Table 2. Differences in Opinion Between Physicians Who Have Recommended Medical Marijuana for a Patient (31\% of Respondents, $n=72)$ and Those Who Have Not (69\% of Respondents, $n=160$ ).

\begin{tabular}{|c|c|c|c|c|c|}
\hline \multirow[b]{3}{*}{ Opinion Statement } & \multicolumn{4}{|c|}{$\underline{\text { Recommended Marijuana for a Patient }}$} & \multirow[b]{3}{*}{$P$} \\
\hline & \multicolumn{2}{|c|}{ Yes } & \multicolumn{2}{|c|}{ No } & \\
\hline & \% Agree & (n) & \% Agree & (n) & \\
\hline Physicians should recommend marijuana as a medical therapy. & 17 & $(19)$ & 7 & $(8)$ & $<0.001$ \\
\hline Marijuana helps patients who suffer from chronic debilitating medical conditions. & 37 & $(53)$ & 44 & $(62)$ & $<0.001$ \\
\hline There are significant physical health benefits to using marijuana. & 18 & $(24)$ & 13 & $(17)$ & $<0.001$ \\
\hline Doctors should not have financial relationships with marijuana dispensaries. & 28 & $(57)$ & 67 & $(136)$ & 0.03 \\
\hline The FDA should reclassify marijuana so that it is no longer a Schedule I drug. & 32 & $(54)$ & 41 & $(70)$ & $<0.001$ \\
\hline There are significant mental health benefits to using marijuana. & 15 & $(21)$ & 8 & $(11)$ & $<0.001$ \\
\hline Medical marijuana should be distributed through the current dispensary model & 19 & $(21)$ & 18 & $(20)$ & $<0.001$ \\
\hline Marijuana should be legalized for recreational use. & 26 & $(43)$ & 36 & $(60)$ & 0.01 \\
\hline $\begin{array}{l}\text { Physicians should have formal training about medical marijuana before } \\
\text { recommending it to patients. }\end{array}$ & 26 & $(50)$ & 70 & $(138)$ & $<0.001$ \\
\hline Marijuana can be addictive. & 22 & $(43)$ & 62 & $(120)$ & $<0.001$ \\
\hline Using marijuana poses serious mental health risks. & 20 & $(33)$ & 67 & $(110)$ & $<0.001$ \\
\hline Using marijuana poses serious physical health risks. & 16 & $(25)$ & 65 & $(100)$ & 0.005 \\
\hline
\end{tabular}

FDA, US Food and Drug Administration.

Percentage and number columns show the percentage and number of respondents from each category who agreed or strongly agreed with each statement on the left. $P$ values are for the $\chi^{2}$ Test of Independence 
Table 3. Differences in Opinion About Medical Marijuana Between Physicians in 2020 Compared to 2011.

\begin{tabular}{|c|c|c|c|c|c|c|c|}
\hline \multirow[b]{2}{*}{ Opinion Statement } & \multicolumn{2}{|c|}{2011} & \multicolumn{2}{|c|}{2020} & \multirow[b]{2}{*}{$\chi^{2}$} & \multirow[b]{2}{*}{ Odds Ratio (95\% CI) } & \multirow[b]{2}{*}{$P$} \\
\hline & $\%$ & (n) & $\%$ & (n) & & & \\
\hline \multicolumn{8}{|c|}{ Physicians should recommend marijuana as a medical therapy. } \\
\hline Agree & 19.14 & 94 & 12.28 & 27 & 1.23 & $0.76(0.46,1.24)$ & 0.27 \\
\hline Disagree & 46.43 & 227 & 39.09 & 86 & & & \\
\hline \multicolumn{8}{|c|}{ Marijuana can be addictive. } \\
\hline Agree & 74.69 & 364 & 74.89 & 164 & 0.50 & $0.84(\mathrm{I} .53,1.35)$ & 0.48 \\
\hline Disagree & 11.83 & 58 & 14.16 & 31 & & & \\
\hline \multicolumn{8}{|c|}{ Using marijuana poses serious physical health risks. } \\
\hline Agree & 60.73 & 296 & 57.73 & 127 & 1.31 & $1.32(0.82,2.12)$ & 0.25 \\
\hline Disagree & 17.59 & 86 & 12.73 & 28 & & & \\
\hline \multicolumn{8}{|c|}{ Using marijuana poses serious mental health risks. } \\
\hline Agree & 63.88 & 312 & 65.71 & 145 & 2.92 & $1.56(0.93,2.62)$ & 0.09 \\
\hline Disagree & 15.10 & 74 & 10.0 & 22 & & & \\
\hline \multicolumn{8}{|c|}{ There are significant physical health benefits to using marijuana . } \\
\hline Agree & 26.83 & 131 & 18.63 & 41 & 2.68 & $0.70(0.45,1.07)$ & 0.10 \\
\hline Disagree & 41.06 & 201 & 40.91 & 90 & & & \\
\hline \multicolumn{8}{|c|}{ There are significant mental health benefits to using marijuana. } \\
\hline Agree & 14.69 & 72 & 14.54 & 32 & 0.06 & $1.06(0.66,1.70)$ & 0.80 \\
\hline Disagree & 54.10 & 263 & 50 & 110 & & & \\
\hline \multicolumn{8}{|c|}{ Marijuana helps patients who suffer from chronic debilitating medical conditions. } \\
\hline Agree & 52.76 & 257 & 52.97 & 116 & 2.61 & $1.49(0.92,2.41)$ & 0.11 \\
\hline Disagree & 18.40 & 89 & 12.33 & 27 & & & \\
\hline \multicolumn{8}{|c|}{ The FDA should reclassify marijuana so that it is no longer a Schedule I drug. } \\
\hline Agree & 37.27 & 183 & 57.27 & 126 & 37.32 & $3.30(2.23,4.90)$ & $<0.0001$ \\
\hline Disagree & 44.40 & 216 & 20.45 & 45 & & & \\
\hline \multicolumn{8}{|c|}{ Marijuana should be legalized for recreational use. } \\
\hline Agree & 30.20 & 148 & 47.73 & 105 & 30.33 & $2.83(1.94,4.12)$ & $<0.0001$ \\
\hline Disagree & 50.00 & 243 & 27.73 & 61 & & & \\
\hline
\end{tabular}

Medical marijuana should be included in the Colorado Prescription Drug Monitoring Program, which tracks prescribing and dispensing of controlled substances.

$\begin{array}{lrrrrrrr}\text { Agree } & 76.33 & 373 & 61.82 & 136 & 10.02 & 0.50(0.33,0.77) & 0.0015 \\ \text { Disagree } & 12.86 & 62 & 20.45 & 45 & & \end{array}$

Doctors should have ongoing relationships with patients for whom they recommend medical marijuana.

$\begin{array}{lrrrrrrr}\text { Agree } & 91.82 & 448 & 91.36 & 201 & 1.19 & 0.58(0.21,1.57) & 0.28 \\ \text { Disagree } & 1.84 & 9 & 3.18 & 7 & & & \\ \text { Medical marijuana should be distributed } & \text { through the current dispensary } & \text { model. } & & & \\ \text { Agree } & 9.57 & 47 & 19.09 & 42 & 30.84 & 3.78(2.32,6.16) \\ \text { Disagree } & 62.93 & 309 & 33.18 & 73 & & \end{array}$

Doctors should not have financial relationships with marijuana dispensaries.

$\begin{array}{lrrrrrrr}\text { Agree } & 94.30 & 464 & 88.18 & 194 & 4.7 & 0.38(0.15,0.94) & 0.03 \\ \text { Disagree } & 1.82 & 9 & 4.54 & 10 & & \end{array}$

Training about medical marijuana should be incorporated into medical school curricula

\begin{tabular}{|c|c|c|c|c|c|c|c|}
\hline Agree & 80.00 & 392 & 89.55 & 197 & 5.23 & $4.77(1.10,20.70)$ & 0.022 \\
\hline Disagree & 3.88 & 19 & 0.90 & 2 & & & \\
\hline
\end{tabular}

Training about medical marijuana should be incorporated into family medicine residency curricula

$\begin{array}{lrrrrrrr}\text { Agree } & 81.67 & 401 & 89.54 & 197 & 3.47 & 2.46(0.93,6.51) & 0.063 \\ \text { Disagree } & 5.09 & 25 & 2.27 & 5 & & \end{array}$




\begin{tabular}{|c|c|c|c|c|c|c|c|}
\hline \multirow[b]{2}{*}{ Opinion Statement } & \multicolumn{2}{|c|}{2011} & \multicolumn{2}{|c|}{2020} & \multirow[b]{2}{*}{$\chi^{2}$} & \multirow[b]{2}{*}{ Odds Ratio (95\% CI) } & \multirow[b]{2}{*}{$H$} \\
\hline & $\%$ & (n) & $\%$ & (n) & & & \\
\hline \multicolumn{8}{|c|}{ CME about medical marijuana should be available to primary care physicians } \\
\hline Agree & 91.65 & 450 & 96.36 & 212 & 0.33 & $1.88(0.21,17.00)$ & 0.60 \\
\hline Disagree & 0.81 & 4 & 0.45 & 1 & & & \\
\hline Agree & 80.86 & 397 & 85.91 & 189 & 0.74 & $1.43(0.63,3.24)$ & 0.39 \\
\hline Disagree & 4.89 & 24 & 3.64 & 8 & & & \\
\hline
\end{tabular}

CI, confidence interval; CME, continuing medical education; FDA, US Food and Drug Administratio0n.

"Agree" represents those who answered either "agree" or "strongly agree" to the given opinion statement. "disagree" represents those who answered either "disagree" or "strongly disagree." Percentages in each column represent agreement with the statement; counts represent total of item responses for that column. Percentages do not add up to 100 as the "Neither Agree nor Disagree" responses were not included in the analysis. $P$ values and odds ratios with $95 \%$ CIs Are for the $\chi^{2}$ Test of Independence.

disagreed with this statement). The exceptions to this are the statements that "The FDA should reclassify marijuana so that it is no longer a Schedule I drug" and "marijuana should be legalized for recreational use." Both of these statements showed significant differences in responses between 2011 and 2020 and also had a change in the majority opinions, with most respondents agreeing with these statements in 2020, while most disagreed in 2011.

\section{Conclusion}

When we conducted our 2011 survey, medical marijuana was a new issue confronting primary care physicians in the 16 states where it was permitted at that time. In the intervening 9 years, there has been a trend toward legislation permitting medical marijuana across the country, expansions of the medical indications for medical marijuana use in many of these states, and more recent adoption of laws allowing for recreational marijuana use that have led to wider availability of marijuana to patients.

These changes in marijuana legislation have medical, behavioral health, financial, and legal implications for physicians and their patients. Our study is the first to assess the effects of these changes in the lives of family physicians. Interestingly, our study found largely stable patterns in Colorado family physician behavior around medical marijuana over the past 9 years, even as the availability and visibility of marijuana changed around them. The same percentage of physicians reported recommending marijuana to a patient in the 2011 and 2020 surveys. A greater number of physicians remained concerned about the risks of medical marijuana than felt that there were significant benefits to its use. This stability in a shifting landscape may reflect lack of major changes in the scientific evidence base and practice guidelines endorsed by professional societies. Evidence for this possibility includes the ongoing high levels of support for medical education around medical marijuana at all levels of training. These practice patterns and opinions may also be influenced by some practice policies that do not permit employed physicians to issue formal marijuana recommendations for patients.

While there were not significant changes in perceptions of risks and benefits of medical marijuana or in the percentage of physicians recommending it to patients, there were changes in attitudes toward the regulatory environment around medical marijuana. Significantly more physicians in 2020 felt that marijuana should be reclassified by the FDA so that is no longer a Schedule I drug, and the proportion of physicians who agreed that recreational marijuana should be legalized increased from 38\% in 2011 to $63 \%$ in 2020 . This may represent greater comfort with recreational marijuana after 6 years of recreational sales in Colorado and may also reflect a desire not to be "gatekeepers" to marijuana use for patients, something about which many physicians expressed frustration in 2011, when medical marijuana was permitted only with a formal physician. While most physicians still agreed that marijuana should be included in the state Prescription Drug Monitoring Program and disagreed that medical marijuana should be distributed through the current dispensary model, they were significantly less 
likely to do so in 2020 than in 2011, again suggesting greater comfort with the current system in Colorado and with deregulation of marijuana.

Another change was observed in the subset of physicians who reported ever recommending marijuana. In our 2020 sample, a larger percentage of physicians reported recommending marijuana for each approved condition compared with the percentages who had recommended marijuana for those conditions in 2011, with the exceptions of severe nausea and persistent muscle spasm. This may reflect a longer period of time for an individual to recommend marijuana leading to a greater number of conditions represented or may indicate greater comfort with recommendation for multiple conditions. Interestingly, although the indications for medical marijuana in Colorado expanded between 2011 and 2020 to include autism spectrum disorder and PTSD, this did not seem to have an impact on overall attitudes and did not increase the percentage of family physicians who recommended marijuana to patients.

While the main sources of physician information about medical marijuana remained medical literature and experiences with patients in both surveys, there was a substantial increase in the percentage of physicians who said that they got most of their information about medical marijuana from experiences with patients, other physicians, and from lectures or CME (see Figure 2). There was a substantial decrease in the percentage who said they received most of their information from the news media. This suggests that efforts to create more $\mathrm{CME}$ around this topic have been successful and may have filled a need that was previously being filled by less rigorous information from the news media. It also suggests that physicians are relying more heavily on the experience they and their colleagues have accrued around medical marijuana over the past 9 years.

There are several limitations that should be kept in mind when interpreting our findings. The response rate of $15 \%$ is a decrease from the response rate of $30 \%$ obtained for the original 2011 survey. While this has the potential to introduce sampling bias, it is equal to or higher than average response rates for Internet-based physician surveys. ${ }^{19}$ In 2011, medical marijuana was relatively new and a more controversial "hot topic" about which many family physicians were eager to share their opinions. To our knowledge, the 2011 survey was the first research survey distributed by the CAFP, while in 2020 the CAFP was sending out several other surveys in the same data collection window as ours. These, in addition to the multiple other venues through which physicians receive surveys, can lead to "survey fatigue" and decreased visibility of individual survey instruments among competing studies, which we believe likely also contributed to the lower response rate. ${ }^{20}$ Despite this limitation, respondent demographics reflect a representative sample of the overall CAFP membership (see Table 1). While the individual participants who completed the 2020 survey were not the same as those who completed the 2011 survey, our intent with this research was not to assess how individual attitudes changed but how the attitudes of this community of active family physicians in Colorado (whose membership would have naturally changed over this time period) had changed over time.

We surveyed only family physicians in Colorado, so these findings may not be generalizable to physicians in other states or other medical specialties. However, as described above, Colorado has been a front-runner in marijuana legislation and infrastructure. Other states have followed its trajectory in many ways over the past 2 decades and will likely continue to do so.

We have seen major changes in the climate around marijuana use and the availability of marijuana as a potential medical therapy, but formally recommending marijuana to patients remains the province of a minority of primary care physicians. This study affirms that, even as the regulatory landscape shifted from 2011 to 2020 , the increasing number of permitted medical uses of medical marijuana and permission of recreational marijuana use has not led to decreased perception of the risks of marijuana use or increased formal recommendation of marijuana to patients by family physicians. It does seem to have led to greater support for legalization of recreational marijuana and deregulation of marijuana.

The authors would like to thank Donald E Nease, Jr, MD, and Matthew Simpson, MD, for their review of the manuscript. They would also like to acknowledge Joshua Foust and Raquel Alexander at the Colorado Academy of Family Physicians for their help in distributing this survey.

To see this article online, please go to: http://jabfm.org/content/ 35/1/102.full. 


\section{References}

1. National Conference of State Legislatures [Internet]. Marijuana overview; 2020 [cited 2021 Feb 4]. Available from: http://www.ncsl.org/research/civiland-criminal-justice/marijuana-overview.aspx.

2. Nugent SM, Morasco BJ, O'Neil ME, et al. The effects of cannabis among adults with chronic pain and an overview of general harms: a systematic review. Ann Intern Med 2017;167:319-31.

3. O’Neil ME, Nugent SM, Morasco BJ, et al. Benefits and harms of plant-based cannabis for posttraumatic stress disorder: a systematic review. Ann Intern Med 2017;167:332-40.

4. Smith LA, Azariah F, Lavender VTC, Stoner NS, Bettiol S, Cochrane Gynaecological, Neuro-oncology and Orphan Cancer Group. Cannabinoids for nausea and vomiting in adults with cancer receiving chemotherapy. Cochrane Database Syst Rev 2015;11:CD009464.

5. O'Connell BK, Gloss D, Devinsky O. Cannabinoids in treatment-resistant epilepsy: a review. Epilepsy Behav 2017;70:341-8.

6. Whiting PF, Wolff RF, Deshpande S, et al. Cannabinoids for medical use: a systematic review and meta-analysis. JAMA 2015;313:2456-73.

7. Kondrad E, Reid AO. Colorado family physicians' attitudes towards medical marijuana. J Am Board Fam Med 2013;26:52-60.

8. Philpot LM, Ebbert JO, Hurt RT. A survey of the attitudes, beliefs and knowledge about medical cannabis among primary care providers. BMC Fam Pract 2019;20:17.

9. Sideris A, Khan F, Boltunova A, Cuff G, Gharibo C, Doan LV. New York physicians' perspectives and knowledge of the state medical marijuana program. Cannabis Cannabinoid Res 2018;3:74-84.

10. Chan MH, Knoepke CE, Cole ML, McKinnon J, Matlock DD. Colorado medical students' attitudes and beliefs about marijuana. J Gen Intern Med 2017;32:458-63.

11. Takakuwa KM, Shofer FS, Schears RM. The practical knowledge, experience and beliefs of US emergency medicine physicians regarding medical cannabis: a national survey. Am J Emerg Med 2020;38:1952-4.

12. Szaflarski M, McGoldrick P, Currens L, et al. Attitudes and knowledge about cannabis and cannabis-based therapies among US neurologists, nurses, and pharmacists. Epilepsy Behav 2020;109: 107102

13. Braun IM, Blonquist TM, Campbell EG, Nayak MM, Bolcic-Jankovic D, Wright AA. Medical oncologists' views on the utility of medical marijuana across the cancer trajectory. J Pain Symptom Manage 2019; 57:e1-e4.

14. Volkow ND, Baler RD, Compton WM, Weiss SR. Adverse health effects of marijuana use. N Engl J Med 2014;370:2219-27.

15. Colorado Department of Revenue [Internet]. Colorado marijuana industry continues to grow, revenue surpasses $\$ 1$ billion to date [Press release]; 2019. Available from: https://www.colorado.gov/ pacific/sites/default/files/NewsRelease \%241B\% 20 inmarijuanatax\%20revenue.pdf.

16. Rubino J [Internet]. June was Colorado's biggest marijuana sales month ever. July was likely bigger. Denver Post; 2020 [cited 2021 Feb 1]. Available from: https://www.denverpost.com/2020/08/12/june2020-colorado-marijuana-sales-record/.

17. Colorado Department of Revenue [Internet]. MED resources and statistics: January 2021 [cited 2021 Jan 21]. Available from: https://www.colorado.gov/ pacific/enforcement/med-resources-and-statistics.

18. Keul A, Eisenhauer B. Making the high country: cannabis tourism in Colorado USA. Ann Leis Res 2019;22:140-60.

19. Cook DA, Wittich CM, Daniels WL, West CP, Harris AM, Beebe TJ. Incentive and reminder strategies to improve response rate for internet-based physician surveys: a randomized experiment. J Med Internet Res 2016;18:e244e244.

20. Porter SR, Whitcomb ME, Weitzer WH. Multiple surveys of students and survey fatigue. New Dir Inst Res 2004;2004:63-73. 
Table A1. Physician Responses to Each Opinion Statement in 2011 and 2020.

\begin{tabular}{|c|c|c|c|c|c|c|c|c|c|c|c|}
\hline \multirow{3}{*}{$\begin{array}{l}\text { Opinion Statement } \\
\text { Physicians should } \\
\text { recommend marijuana as a } \\
\text { medical therapy. }\end{array}$} & \multirow{2}{*}{$\begin{array}{c}\text { Survey } \\
\text { Year }\end{array}$} & \multicolumn{2}{|c|}{$\begin{array}{c}\text { Strongly } \\
\text { Disagree\% (n) }\end{array}$} & \multicolumn{2}{|c|}{ Disagree\% (n) } & \multicolumn{2}{|c|}{$\begin{array}{c}\text { Neither } \\
\text { Agree nor } \\
\text { Disagree\% (n) }\end{array}$} & \multicolumn{2}{|c|}{ Agree\% (n) } & \multicolumn{2}{|c|}{$\begin{array}{c}\text { Strongly } \\
\text { Agree\% (n) }\end{array}$} \\
\hline & & $11 \%$ & 24 & $28 \%$ & 62 & $49 \%$ & 107 & $9 \%$ & 19 & $4 \%$ & 8 \\
\hline & 2011 & $23 \%$ & 112 & $24 \%$ & 116 & $34 \%$ & 169 & $16 \%$ & 79 & $3 \%$ & 15 \\
\hline \multirow[t]{2}{*}{ Marijuana can be addictive. } & 2020 & $2 \%$ & 4 & $12 \%$ & 27 & $11 \%$ & 24 & $48 \%$ & 105 & $27 \%$ & 59 \\
\hline & 2011 & $2 \%$ & 12 & $9 \%$ & 46 & $13 \%$ & 66 & $45 \%$ & 221 & $30 \%$ & 145 \\
\hline \multirow{2}{*}{$\begin{array}{l}\text { Using marijuana poses } \\
\text { serious physical health } \\
\text { risks. }\end{array}$} & 2020 & $3 \%$ & 7 & $10 \%$ & 21 & $30 \%$ & 65 & $42 \%$ & 92 & $16 \%$ & 35 \\
\hline & 2011 & $2 \%$ & 10 & $16 \%$ & 76 & $22 \%$ & 106 & $41 \%$ & 201 & $20 \%$ & 96 \\
\hline \multirow{2}{*}{$\begin{array}{l}\text { Using marijuana poses } \\
\text { serious mental health } \\
\text { risks. }\end{array}$} & 2020 & $2 \%$ & 5 & $8 \%$ & 17 & $24 \%$ & 53 & $42 \%$ & 92 & $24 \%$ & 53 \\
\hline & 2011 & $2 \%$ & 12 & $13 \%$ & 62 & $21 \%$ & 103 & $41 \%$ & 201 & $23 \%$ & 112 \\
\hline \multirow{2}{*}{$\begin{array}{l}\text { There are significant } \\
\text { physical health benefits to } \\
\text { using marijuana. }\end{array}$} & 2020 & $10 \%$ & 22 & $31 \%$ & 68 & $40 \%$ & 89 & $16 \%$ & 36 & $2 \%$ & 5 \\
\hline & 2011 & $12 \%$ & 58 & $29 \%$ & 144 & $32 \%$ & 158 & $24 \%$ & 117 & $3 \%$ & 15 \\
\hline \multirow{2}{*}{$\begin{array}{l}\text { There are significant mental } \\
\text { health benefits to using } \\
\text { marijuana. }\end{array}$} & 2020 & $18 \%$ & 39 & $32 \%$ & 71 & $35 \%$ & 78 & $12 \%$ & 27 & $2 \%$ & 5 \\
\hline & 2011 & $20 \%$ & 98 & $34 \%$ & 167 & $31 \%$ & 153 & $12 \%$ & 59 & $3 \%$ & 13 \\
\hline \multirow{2}{*}{$\begin{array}{l}\text { Marijuana helps patients } \\
\text { who suffer from chronic } \\
\text { debilitating medical } \\
\text { conditions. }\end{array}$} & 2020 & $2 \%$ & 5 & $10 \%$ & 22 & $35 \%$ & 76 & $48 \%$ & 106 & $5 \%$ & 10 \\
\hline & 2011 & $5 \%$ & 24 & $13 \%$ & 66 & $29 \%$ & 141 & $46 \%$ & 223 & $7 \%$ & 35 \\
\hline \multirow{2}{*}{$\begin{array}{l}\text { The FDA should reclassify } \\
\text { marijuana so that it is no } \\
\text { longer a Schedule I drug. }\end{array}$} & 2020 & $10 \%$ & 23 & $10 \%$ & 22 & $22 \%$ & 49 & $29 \%$ & 64 & $28 \%$ & 62 \\
\hline & 2011 & $20 \%$ & 100 & $24 \%$ & 118 & $18 \%$ & 90 & $23 \%$ & 113 & $14 \%$ & 70 \\
\hline \multirow{2}{*}{$\begin{array}{l}\text { Marijuana should be } \\
\text { legalized for recreational } \\
\text { use. }\end{array}$} & 2020 & $14 \%$ & 31 & $14 \%$ & 30 & $25 \%$ & 54 & $33 \%$ & 72 & $15 \%$ & 33 \\
\hline & 2011 & $29 \%$ & 141 & $21 \%$ & 104 & $20 \%$ & 97 & $20 \%$ & 98 & $10 \%$ & 50 \\
\hline \multirow[b]{2}{*}{$\begin{array}{l}\text { Medical marijuana should be } \\
\text { included in the Colorado } \\
\text { Prescription Drug } \\
\text { Monitoring Program, } \\
\text { which tracks prescribing } \\
\text { and dispensing of } \\
\text { controlled substances. }\end{array}$} & 2020 & $5 \%$ & 12 & $15 \%$ & 33 & $18 \%$ & 39 & $40 \%$ & 88 & $22 \%$ & 48 \\
\hline & 2011 & $6 \%$ & 30 & $7 \%$ & 33 & $11 \%$ & 53 & $36 \%$ & 175 & $41 \%$ & 199 \\
\hline \multirow{2}{*}{$\begin{array}{l}\text { Doctors should have } \\
\text { ongoing relationships with } \\
\text { patients for whom they } \\
\text { recommend medical } \\
\text { marijuana. }\end{array}$} & 2020 & $0 \%$ & 0 & $3 \%$ & 7 & $5 \%$ & 12 & $45 \%$ & 99 & $46 \%$ & 102 \\
\hline & 2011 & $1 \%$ & 5 & $1 \%$ & 4 & $6 \%$ & 31 & $31 \%$ & 153 & $61 \%$ & 296 \\
\hline \multirow{2}{*}{$\begin{array}{l}\text { Medical marijuana should be } \\
\text { distributed through the } \\
\text { current dispensary model. }\end{array}$} & 2020 & $14 \%$ & 31 & $19 \%$ & 42 & $48 \%$ & 105 & $15 \%$ & 33 & $4 \%$ & 9 \\
\hline & 2011 & $35 \%$ & 170 & $29 \%$ & 140 & $27 \%$ & 134 & $7 \%$ & 35 & $2 \%$ & 12 \\
\hline \multirow{2}{*}{$\begin{array}{l}\text { Doctors should not have } \\
\text { financial relationships with } \\
\text { marijuana dispensaries. }\end{array}$} & 2020 & $0 \%$ & 1 & $4 \%$ & 9 & $7 \%$ & 16 & $28 \%$ & 61 & $60 \%$ & 133 \\
\hline & 2011 & $1 \%$ & 4 & $1 \%$ & 5 & $3 \%$ & 17 & $23 \%$ & 114 & $72 \%$ & 352 \\
\hline \multirow{2}{*}{$\begin{array}{l}\text { Training about medical } \\
\text { marijuana should be } \\
\text { incorporated into medical } \\
\text { school curricula. }\end{array}$} & 2020 & $0 \%$ & 1 & $0 \%$ & 1 & $10 \%$ & 21 & $45 \%$ & 98 & $45 \%$ & 99 \\
\hline & 2011 & $2 \%$ & 12 & $2 \%$ & 8 & $16 \%$ & 78 & $53 \%$ & 261 & $27 \%$ & 131 \\
\hline \multirow{2}{*}{$\begin{array}{l}\text { Training about medical } \\
\text { marijuana should be } \\
\text { incorporated into family }\end{array}$} & 2020 & $0 \%$ & 1 & $2 \%$ & 4 & $8 \%$ & 18 & $44 \%$ & 96 & $46 \%$ & 101 \\
\hline & 2011 & $3 \%$ & 14 & $2 \%$ & 12 & $13 \%$ & 63 & $56 \%$ & 275 & $26 \%$ & 127 \\
\hline
\end{tabular}

Continued 


\begin{tabular}{|c|c|c|c|c|c|c|c|c|c|c|c|}
\hline \multirow{2}{*}{$\begin{array}{l}\text { Opinion Statement } \\
\text { medicine residency } \\
\text { curricula. }\end{array}$} & \multirow[t]{2}{*}{$\begin{array}{l}\text { Survey } \\
\text { Year }\end{array}$} & \multicolumn{2}{|c|}{$\begin{array}{c}\text { Strongly } \\
\text { Disagree\% (n) }\end{array}$} & \multicolumn{2}{|c|}{ Disagree\% (n) } & \multicolumn{2}{|c|}{$\begin{array}{c}\text { Neither } \\
\text { Agree nor } \\
\text { Disagree\% (n) }\end{array}$} & \multicolumn{2}{|c|}{ Agree\% (n) } & \multicolumn{2}{|c|}{$\begin{array}{c}\text { Strongly } \\
\text { Agree\% (n) }\end{array}$} \\
\hline & & & & & & & & & & & \\
\hline \multirow{2}{*}{$\begin{array}{l}\text { CME about medical } \\
\text { marijuana should be } \\
\text { available to primary care } \\
\text { physicians. }\end{array}$} & 2020 & $0 \%$ & 0 & $0 \%$ & 1 & $3 \%$ & 7 & $45 \%$ & 99 & $51 \%$ & 113 \\
\hline & 2011 & $1 \%$ & 4 & $0 \%$ & 1 & $7 \%$ & 35 & $59 \%$ & 292 & $32 \%$ & 159 \\
\hline \multirow{2}{*}{$\begin{array}{l}\text { Physicians should have } \\
\text { formal training about } \\
\text { medical marijuana prior to } \\
\text { recommending it to } \\
\text { patients. }\end{array}$} & 2020 & $0 \%$ & 0 & $4 \%$ & 8 & $10 \%$ & 23 & $41 \%$ & 90 & $45 \%$ & 99 \\
\hline & 2011 & $1 \%$ & 3 & $4 \%$ & 21 & $14 \%$ & 68 & $41 \%$ & 201 & $40 \%$ & 198 \\
\hline
\end{tabular}

CME, continuing medical education; FDA, US Food and Drug Administration.

Each opinion statement Is followed by the numbers of responses to each choice (strongly disagree through strongly agree) on the 5point likert scale and the percent of responses for each choice. 


\section{Appendix 2.}

Colorado Family Physician Medical Marijuana Follow Up Survey

There have been sweeping changes in marijuana legislation nationwide in the past several years. Medical marijuana is now legal in 33 states and the District of Columbia, and recreational use has been approved in $\mathbf{1 3}$ of these states. Little is known about how these changes have affected physician attitudes and practices. Thank you for your contribution.

Q1 How old are you?

$$
\begin{array}{ll}
\text { O } & 20-29(1) \\
0 & 30-39(2) \\
0 & 40-49(3) \\
0 & 50-59(4) \\
\text { O } & 60-69(5) \\
\text { O } & 70-79(6) \\
\text { O } & 80+(7)
\end{array}
$$

Q2 Are you:

O Male (1)

O Female (2)

Q3 Do you have a full and unrestricted license?

O Yes (1)

O No (2)

$\circ$ Unsure (3)

Q4 How many years have you been in practice?

O $0-4(1)$

O $5-9(2)$

O $10-19(3)$

O $20-29(4)$

O $20-29(4)$

O $40+(6)$

According to Colorado law, physicians cannot prescribe medical marijuana. If they believe a patient may benefit from medical marijuana, they can recommend to the Colorado Department of Public Health and the Environment that the patient be added to the state's Medical Marijuana Registry.

Q6 Does your practice have a policy about the recommendation of medical marijuana?

O Yes (1)

O No (2)

O Unsure (3)

Q7 If yes, which of the following best describes that policy?

O My practice policy prohibits me from recommending medical marijuana to patients. (1)

- My practice policy permits me to recommend medical marijuana to patients. (2)

O I am not sure what my practice policy is. (3)

Other (please specify): (4)

Q8 Have you ever personally recommended medical marijuana to a patient?

$O$ Yes (1)

No (2)

Q9 If yes, estimate how many patients you personally have recommended medical marijuana for in the past twelve months?

○ 0 (1)

○ $1-5$ (2)

O $6-10$ (3)

O $11-20$ (4)

O $21-50(5)$

O $51-99(6)$

O $100-500(7)$

O $500+(8)$

Q10 Has the legalization of recreational marijuana in Colorado changed your approach to medical marijuana?
O No (1)

O Yes, it has made me MORE likely to recommend marijuana to patients for medical purposes (2)

O Yes, it has made me LESS likely to recommend marijuana to patients for medical purposes (3)

Other (please specify): (4)

Q11 For which conditions have you recommended medical marijuana? (check all that apply)

व cancer (1)

glaucoma (2)

口 HIV/AIDS (3)

cachexia (4)

口 severe pain (5)

severe nausea (6)

$\square$ seizures (7)

persistent muscle spasm (8)

post-traumatic stress disorder (PTSD) (9)

a autism spectrum disorder (10)

$\checkmark$ other (please specify): (11)

Q12 Where have you gotten most of your information about medical marijuana? (check all that apply)

medical literature (1)

news media (2)

$\square$ friends/family (3)

dispensary owners (4)

other physicians (5)

$\square$ experiences with patients (6)

$\checkmark$ practice policy (7)

口 CME (8)

lecture (9)

$\square$ other (please specify): (10)

Q13 Which of the following have influenced your decision to recommend medical marijuana to patients? (check all that apply)

medical literature (1)

$\checkmark$ news media (2)

dispensary owners (3)

other physicians (4)

$\square$ experiences with patients (5)

$\square$ personal use for medical reasons (6)

$\square$ personal recreational use (7)

- friend/family member use for medical reasons ( 8 )

口 friend/family member recreational use (9)

practice policy $(10)$

口 CME (11)

$\square$ lecture (12)

- legalization of recreational marijuana

other (please specify) (13)

Q14 Which of the following have influenced your decision not to recommend medical marijuana to patients? (check all that apply)

a medical literature (1)

$\square$ news media (2)

a personal use for medical reasons (3)

personal recreational use (4)

- friend/family member use for medical reasons (5)

friend/family member recreational use (6)

a dispensary owners (7)

other physicians (8)

- experiences with patients (9)

practice policy (10)

口 CME (11)

口 lecture (12)

- legalization of recreational marijuana

口 other (please specify): (13) 


\begin{tabular}{|c|c|c|c|c|c|}
\hline & $\begin{array}{l}\text { Strongly } \\
\text { Disagree } \\
\text { (1) }\end{array}$ & $\begin{array}{l}\text { Disagree } \\
\text { (2) }\end{array}$ & $\begin{array}{l}\text { Neither } \\
\text { Agree } \\
\text { nor } \\
\text { Disagree } \\
\text { (3) }\end{array}$ & $\begin{array}{l}\text { Agree } \\
\text { (4) }\end{array}$ & $\begin{array}{l}\text { Strongly } \\
\text { Agree } \\
\text { (5) }\end{array}$ \\
\hline $\begin{array}{l}\text { Physicians should recommend marijuana as a medical } \\
\text { therapy. (1) }\end{array}$ & $\mathrm{o}$ & $\mathrm{o}$ & o & 0 & o \\
\hline Marijuana can be addictive. (2) & $\mathrm{o}$ & o & O & 0 & o \\
\hline Using marijuana poses serious physical health risks. & O & O & O & o & O \\
\hline Using marijuana poses serious mental health risks. (4) & o & o & 0 & 0 & o \\
\hline $\begin{array}{r}\text { There are significant physical health benefits to using } \\
\text { marijuana. (5) }\end{array}$ & o & $\mathrm{o}$ & o & 0 & o \\
\hline $\begin{array}{r}\text { There are significant mental health benefits to using } \\
\text { marijuana. (6) }\end{array}$ & o & 0 & 0 & 0 & 0 \\
\hline $\begin{array}{r}\text { Marijuana helps patients who suffer from chronic } \\
\text { debilitating medical conditions. (7) }\end{array}$ & o & o & o & 0 & 0 \\
\hline $\begin{array}{r}\text { The FDA should reclassify marijuana so that it is no } \\
\text { longer a Schedule I drug. (8) }\end{array}$ & $\mathrm{O}$ & o & O & 0 & o \\
\hline Marijuana should be legalized for recreational use. (9) & 0 & o & o & 0 & 0 \\
\hline $\begin{array}{r}\text { Medical marijuana should be included in the Colorado } \\
\text { Prescription Drug Monitoring Program (PDMP), which } \\
\text { tracks prescribing and dispensing of controlled } \\
\text { substances. (10) }\end{array}$ & O & o & o & 0 & $\mathrm{o}$ \\
\hline $\begin{array}{r}\text { Doctors should have ongoing relationships with } \\
\text { patients for whom they recommend medical } \\
\text { marijuana. (11) }\end{array}$ & $\mathrm{O}$ & O & O & 0 & o \\
\hline $\begin{array}{r}\text { Medical marijuana should be distributed through the } \\
\text { current dispensary model. (12) }\end{array}$ & O & o & ○ & 0 & o \\
\hline $\begin{array}{r}\text { Doctors should not have financial relationships with } \\
\text { marijuana dispensaries. (13) }\end{array}$ & O & o & O & 0 & 0 \\
\hline $\begin{array}{l}\text { Training about medical marijuana should be } \\
\text { incorporated into medical school curricula. (14) }\end{array}$ & $\mathrm{O}$ & $\mathrm{O}$ & O & 0 & $\mathrm{O}$ \\
\hline $\begin{array}{l}\text { Training about medical marijuana should be } \\
\text { incorporated into family medicine residency curricula. } \\
\text { (15) }\end{array}$ & O & o & ○ & 0 & O \\
\hline $\begin{array}{r}\text { CME about medical marijuana should be available to } \\
\text { primary care physicians. (16) }\end{array}$ & O & O & O & 0 & O \\
\hline $\begin{array}{l}\text { Physicians should have formal training about medical } \\
\text { marijuana prior to recommending it to patients. (17) }\end{array}$ & $\mathrm{o}$ & $\mathrm{o}$ & 0 & 0 & 0 \\
\hline
\end{tabular}

